\title{
EFFECT OF LIGHT CYCLE ON DIATOM FATTY ACID COMPOSITION AND QUANTITATIVE MORPHOLOGY ${ }^{1}$
}

\author{
Linda Sicko-Goad, ${ }^{2}$ Mila S. Simmons, Diane Lazinsky and Janet Hall \\ Great Lakes Research Division, The University of Michigan, Institute of Science and Technology \\ Ann Arbor, Michigan 48109
}

\begin{abstract}
Quantitative cytological and fatty acid composition was determined for the diatom Cyclotella meneghiniana Kütz. Data from four separate experiments were examined to elucidate changes that may occur with respect to daily photoperiod. Overall, fatty acid composition is similar to that reported for other diatoms with the exception that the C16 fatty acids constitute approximately $70 \%$ of all fatty acids. The major fatty acids are C14:0, 16:1, 16:0, 18: 0 , and 20:5. Fatty acids that are present in minor amounts are iso-14:0, iso-15:0, 15:0, 17:0, 18:4, 18:2, 18:1, 19: $0,20: 0,22: 0$, and 23:0.

Cytological composition is similar to that previously reported with the chloroplast and vacuole being the largest compartments within the cell. Changes in both cytological and fatty acid composition were studied with respect to the light/dark cycle. Chloroplast and lipid relative volume are greatest during the early part of the dark period. Nuclear relative volume is lowest in the dark and increases throughout the light period.

Total unsaturated fatty acids, including the C20:5 fatty acid, are lowest in the early part of the light period and highest in the dark. The sum of the C16 fatty acids remains constant at $70 \%$ of total fatty' acids in the cells throughout the light/dark cycle, although percent composition of these two fatty acids shifts.

The data suggest that cyclical changes occur in both quantitative morphology and fatty acid composition with respect to daily photoperiod. The cells, although not rigidly synchronized, most likely divide in the latter part of the dark period or in the first hours of the light period. Lipids increase dramatically in the dark. The ecological implications of lipid storage are discussed in relation to lipophilic toxicants.
\end{abstract}

Key index words: Cyclotella; diatoms; fatty acids; light cycle; ultrastructure

In phytoplankton, rapidly growing nutrient-sufficient cells incorporate most cell carbon into protein. However, under a variety of stress conditions, particularly those produced by nutrient limitation, more cell carbon is incorporated into lipid and carbohydrate storage products (Fogg 1956, Coombs et al. 1967b, Darley 1977, Shifrin and Chisholm 1981, Varum and Mykelstad 1984, Ben-Amotz et al. 1985, Smith and Geider 1985, Millie 1986, Ganf et al.

\footnotetext{
${ }^{1}$ Accepted: 18 September 1987.

${ }^{2}$ Address for reprints and correspondence.
}

1986). Diatoms accumulate lipids or have altered fatty acid percent compositions as a function of culture age, silicon or nitrogen deficiency, or exposure to heavy metals (Ackman et al. 1964, Werner 1966, Coombs et al. 1967a, Opute 1974, Fisher and Schwarzenbach 1978, Shifrin and Chisholm 1981, Sicko-Goad et al. 1986a, b).

Accumulation of highly hydrophobic compounds appears to be related to lipid content. For example, Canton et al. (1977) found that for hexachlorocyclohexane, Chlamydomonas and Dunaliella had partition coefficients of 2700 and 1500 respectively, on a dry weight basis. However, when these values were normalized to lipid content, the partition coefficients obtained were 12,000 and 13,000. Thus it seems evident that lipid quantities and composition may change as a result of environmental and cultural perturbations and that lipids may be important in terms of uptake, storage, and toxicity of lipophilic compounds (Clayton et al. 1977, Boyles 1980, Hutchinson et al. 1980).

During a study of the effects of chlorinated benzenes on diatom ultrastructure and fatty acid composition, variability in both of these cellular parameters was noted that appeared to be related to the light/dark cycle. Since light is known to affect chloroplast structure (Brown and Richardson 1968, Meier and Lichtenthaler 1981) and fatty acid composition (Pohl and Zurheide 1979, Shifrin and Chisholm 1981), data from control cultures of four separate chlorinated benzene exposure experiments were pooled and compared to determine normal variability in these parameters with reference to the daily photoperiod. Results of this comparison are presented here.

\section{MATERIALS AND METHODS}

The control data compiled in this paper were taken from four separate experiments in which the diatom Cyclotella meneghiniana Kütz. (Clone CYOH2) was exposed to chlorinated benzenes. During the exposure experiments, control cultures were manipulated exactly as experimental cultures. The four exposure experiments were conducted over a period of 12 months from October 1984 to September 1985.

Cells were grown in WC medium (Guillard 1975) on a 16:8 h $\mathrm{LD}$ cycle to logarithmic phase at $20^{\circ} \mathrm{C}$ with a light irradiance of $200 \mu \mathrm{E} \cdot \mathrm{m}^{-2} \cdot \mathrm{s}^{-1}$ as previously described (Sicko-Goad and Lazinsky 1986). Since experiments originally were designed to assess effects of chlorinated benzenes on ultrastructure and fatty acid composition, logarithmic phase cells were harvested at the following times after exposure to the toxicants: $10 \mathrm{~min}, 1 \mathrm{~h}, 2 \mathrm{~h}, 8$ $\mathrm{h}, 24 \mathrm{~h}$, and 5 days. These sampling times also included control cultures with no added toxicant, and these data were pooled to 
form the data base for the present comparison. Since the start of individual experiments did not coincide in all cases, data were divided into three time periods with respect to the daily LD cycle. Those samples described as "early light" were harvested during the first $8 \mathrm{~h}$ of light exposure; those described as "late light" were harvested during the second $8 \mathrm{~h}$ of light exposure; and those harvested during the $8 \mathrm{~h}$ dark period are referred to as "dark" samples. However, since these control data were pooled from toxicant exposure experiments and these experiments were not designed to assess cyclical changes with photoperiod, dark samples were obtained during the first three hours of the dark period, and most light samples were obtained during the second eight hours of the light period. In all cases, however, samples for electron microscopy and fatty acid analysis were withdrawn simultaneously.

Electron microscopy. Samples for electron microscopy were withdrawn into $50 \mathrm{~mL}$ sterile polypropylene centrifuge tubes. Fixative and buffer were added to give final concentrations of $1 \%$ paraformaldehyde, $1 \%$ glutaraldehyde, and $0.05 \mathrm{M}$ cacodylate buffer at $\mathrm{pH} 7.2$ as previously described (Sicko-Goad and Lazinsky 1986). Samples were post-fixed in $1 \% \mathrm{OsO}_{4}$, dehydrated in a graded ethanol-propylene oxide dehydration series and embedded in Embed 812. Sections were cut with a diamond knife, collected on formvar coated 200 mesh copper grids, and stained with aqueous uranyl acctate (Watson 1958). Sections were examined and photographed with a JEOL JEM $100 \mathrm{~B}$ electron microscope operating at $80 \mathrm{kV}$.

The morphometric sampling scheme used has been described in detail (Sicko-Goad et al. 1977, 1984, 1986a) with precautions taken for unbiased sampling of unicells. The only exception to the previously described sampling scheme was that 25 photographs per individual time period in each of four experiments were examined. The point count per individual group of 25 cells was ca. 5000, and standard errors were within $10 \%$ of the mean. The number of individual control cultures analyzed by electron microscopy was 18 , for a total cell count of 450 . The distribution of the number of cells examined with respect to the three time periods defined is indicated in Table 3. All individual photographs within each time period were considered as independent estimates of the quantitative ultrastructure and were treated as individual replicates for that particular portion of the light/dark cycle.

Fatty acid analysis. Culture medium (125 mL) containing cells was withdrawn and filtered through GFC filters. The filter retaining the cells was placed in an aluminum foil wrapped vial containing $3.5 \mathrm{~mL}$ methanol/water (7:3) and $5 \% \mathrm{KOH}$ solution. The solution was bubbled with nitrogen and boiled in a $60^{\circ} \mathrm{C}$ water bath for $2 \mathrm{~h}$ to complete deactivation and saponification. The fatty acids were extracted by filtering the above extract and removing other organics with $2 \mathrm{~mL}$ pentane. The solution was acidified with $2 \mathrm{~mL} 2.3 \mathrm{~N} \mathrm{HCl}$ and the fatty acids were extracted 4 times with $1 \mathrm{~mL}$ pentane. Pooled fractions were then washed with $2 \mathrm{~mL}$ saturated $\mathrm{NaCl}$ and dried over anhydrous sodium sulfate (Schwarzenbach and Fisher 1978).

To esterify the fatty acids to methyl esters, the solvent was evaporated by nitrogen and the extract redissolved with $5 \mathrm{~mL}$ benzene in a vial with a Teflon-lined cap. Boron trifluoride $(0.5$ $\mathrm{mL}$ ) was added and the solution was boiled for $4 \mathrm{~min}$ in a $60^{\circ} \mathrm{C}$ water bath. The solution was then washed with $10 \mathrm{~mL}$ distilled water and the fatty acid methyl esters (FAMEs) were extracted with hexane and dried over anhydrous sodium sulfate (Metcalfe and Schmitz 1961). The pooled extract was concentrated by a nitrogen stream to approximately $10 \mu \mathrm{L}$.

For quantification of the FAMEs, samples were analyzed on a Varian $3700 \mathrm{GC}$ with a DB 5 , (narrow bore, $1 \mu \mathrm{m}$ film), $30 \mathrm{~m}$ fused silica column, equipped with a FID detector and a HP $3900 \mathrm{~A}$ integrator. The GC/FID program consisted of the following conditions: Split mode (58:1), Injector temperature $=250^{\circ}$ $\mathrm{C}$, Detector temperature $=290^{\circ} \mathrm{C}$. The column temperature program was hold $4 \mathrm{~min}$ at $225^{\circ} \mathrm{C}, 4^{\circ} \mathrm{C} / \mathrm{min}$ rate, and $280^{\circ} \mathrm{C}$ hold $20 \mathrm{~min}$. Separation and relative retention times were established with a standard FAME solution consisting of 12:0, 13:0, $14: 0,15: 0,16: 1,16: 0,17: 0,18: 3,18: 2,18: 1,18: 0,19: 0,20: 3$, $20: 2,20: 1,20: 0,21: 0,22: 1,22: 0,23: 0,24: 1$, and 24:0 fatty acids.

To verify fatty acids by gas chromatography/mass spectrometry (GC/MS), one of the triplicate samples from all time and experimental controls was pooled and concentrated. The concentrated sample (pooled from 24 individual replicates) and the standard FAME solution were analyzed on a Finnigan 4000 GC/ MS system with an Incos data acquisition system and the same DB 5 column used in the GC/FID. The split mode was 5.4:1, with essentially the same temperature program as described above. The FAMEs were identified by use of NBS library, with the exception of the 18:4 and 20:5 fatty acids which were not present in the library. These FAMEs were identified by visual examination, and interpretation of the mass spectrum was based on the fragmentation pattern of the FAMEs.

To determine fatty acid percent composition, duplicate samples from 24 individual sampling times were examined. The distribution of the number of individual replicates within the established time periods discussed in this paper are indicated in Tables 1 and 2.

Cell volume estimates. Cell volume estimates were determined by light microscopic measurements of epoxy mounts of fixed cells. Measurements of length and diameter were made of 25 cells for each treatment. Consequently, $\mathbf{n}=100$ for early light period cells, $n=300$ for late light period samples and $n=50$ for dark period cells. Volumes were determined by assumption of a regular geometric shape by the relationship $V=\pi d^{2} h / 4$.

\section{RESULTS}

Fatty acids. Typical fatty acid percent composition for all control cells is presented in Table 1. For Cyclotella meneghiniana, C16 fatty acids predominate, accounting for approximately $70 \%$ of all fatty acids in the cells. Although even numbered carbon fatty acids predominate, we also found four odd numbered carbon saturated fatty acids $(15: 0,17: 0,19$ : 0 , and 23:0), with the C15 fatty acid predominant in the odd numbered chain lengths. The odd numbered carbon fatty acids constitute only approximately $2-3 \%$ of all fatty acids.

Changes were found in fatty acid composition when compared on the basis of time of sampling in the light/dark cycle (Table 2). Total unsaturated fatty acids were lowest in the early part of the light period and highest when sampled in the dark (Fig. 1). Conversely, saturated fatty acids predominated in the early light period. The sum of the C16 fatty acids remained constant throughout the entire LD cycle (ca. 70\%).

Quantitative ultrastructure. The typical morphometric portrait of $C$. meneghiniana is presented in Table 3 . The sum of vacuole, lipid, and polyphosphate relative volume is approximately $27 \%$, which can be assumed to be the total vacuolar volume since lipid and polyphosphates are located in the vacuole. Likewise, chloroplast volume is the sum of chloroplast $\mathrm{V}_{\mathrm{v}}$ (relative volume) and chloroplast lipid $\mathrm{V}_{\mathrm{v}}$, and averages ca. $23.5 \%$. Autophagic-like vacuoles are rare in control cells, comprising less than $0.5 \%$ of the total cell volume. The ranges of all other 
TABLE 1. Fatty acid identification and percent composition with standard errors of all Cyclotella meneghiniana control cells. ${ }^{\text {a }}$

\begin{tabular}{lccr}
\hline \multicolumn{1}{c}{ Fatty acid } & Structure & M.W. & \% Composition \\
\hline $14: 0$ & $\mathrm{C}_{15} \mathrm{H}_{30} \mathrm{O}_{2}$ & 242 & $11.20(0.25)$ \\
ISO13:0 & $\mathrm{C}_{15} \mathrm{H}_{30} \mathrm{O}_{2}$ & 242 & $0.06(0.02)$ \\
ISO 14:0 & $\mathrm{C}_{16} \mathrm{H}_{32} \mathrm{O}_{2}$ & 256 & $0.32(0.04)$ \\
$15: 0$ & $\mathrm{C}_{16} \mathrm{H}_{32} \mathrm{O}_{2}$ & 256 & $1.61(0.08)$ \\
$16: 1(\Delta 9)$ & $\mathrm{C}_{17} \mathrm{H}_{32} \mathrm{O}_{2}$ & 268 & $47.23(1.30)$ \\
$16: 0$ & $\mathrm{C}_{17} \mathrm{H}_{34} \mathrm{O}_{2}$ & 270 & $25.10(1.00)$ \\
$17: 0$ & $\mathrm{C}_{18} \mathrm{H}_{36} \mathrm{O}_{2}$ & 284 & $0.13(0.04)$ \\
$18: 4(\Delta 6,9,12,15)$ & $\mathrm{C}_{19} \mathrm{H}_{30} \mathrm{O}_{2}$ & 290 & $0.75(0.06)$ \\
$18: 2(\Delta 9,12)$ & $\mathrm{C}_{19} \mathrm{H}_{34} \mathrm{O}_{2}$ & 294 & $0.42(0.09)$ \\
$18: 1(\Delta 9)$ & $\mathrm{C}_{19} \mathrm{H}_{36} \mathrm{O}_{2}$ & 296 & $1.34(0.15)$ \\
$18: 0$ & $\mathrm{C}_{19} \mathrm{H}_{38} \mathrm{O}_{2}$ & 298 & $4.90(0.53)$ \\
$19: 0$ & $\mathrm{C}_{20} \mathrm{H}_{40} \mathrm{O}_{2}$ & 312 & $0.19(0.19)$ \\
$20: 5(\Delta 5,8,11,14,17)$ & $\mathrm{C}_{21} \mathrm{H}_{32} \mathrm{O}_{2}$ & 316 & $6.25(0.34)$ \\
$20: 0$ & $\mathrm{C}_{21} \mathrm{H}_{42} \mathrm{O}_{2}$ & 326 & $0.07(0.06)$ \\
$22: 0$ & $\mathrm{C}_{23} \mathrm{H}_{46} \mathrm{O}_{2}$ & 354 & $0.04(0.04)$ \\
$23: 0$ & $\mathrm{C}_{24} \mathrm{H}_{48} \mathrm{O}_{2}$ & 368 & $0.37(0.10)$ \\
\hline
\end{tabular}

a Overall composition was determined by averaging 48 replicates which were taken from four different experiments. Samples were averaged without respect to any time period.

categories are similar to earlier reported values (Sicko-Goad and Lazinsky 1986).

As with the fatty acids, definite changes in ultrastructure can be correlated with the LD cycle (Table 3 ). The chloroplast volume (chloroplast $V_{v}$ and chloroplast lipid $V_{v}$ ) increases throughout the light period and reaches its maximum in the dark. This increase is not due to changes in the chloroplast lipid since this decreases in the late part of the light period and in the dark (Fig. 6).

Lipid volume increases dramatically during the latter part of the light period and in the dark (Fig. 7). Again, as in the summary of all control cells (Table 3 ), total vacuole volume (vacuole $V_{v}$, lipid $\mathrm{V}_{\mathrm{v}}$, and polyphosphate $\mathrm{V}_{\mathrm{v}}$ ) remains constant at approximately $27-28 \%$. Consequently, apparent changes are a direct result of changes in lipid volume. Nucleus relative volume is lowest in the dark and increases with time during the light period. All other cellular volume categories remain relatively constant throughout the $\mathrm{LD}$ cycle.

Micrographs of both dark and light period cells (Figs. 2-5) reveal that although individual sections may be found that exhibit some of the quantitative properties presented in Table 3, no single photograph can readily represent the population analyzed.

\section{DISCUSSION}

Data presented here suggest that a moderate degree of division synchrony exists in control cultures of Cyclotella meneghiniana. This is especially significant when one considers that the data were pooled from four different experiments conducted over a period of 12 months under similar environmental conditions of light intensity and quality, photoperiod, temperature, and nutrient conditions. Although a moderate degree of division synchrony has

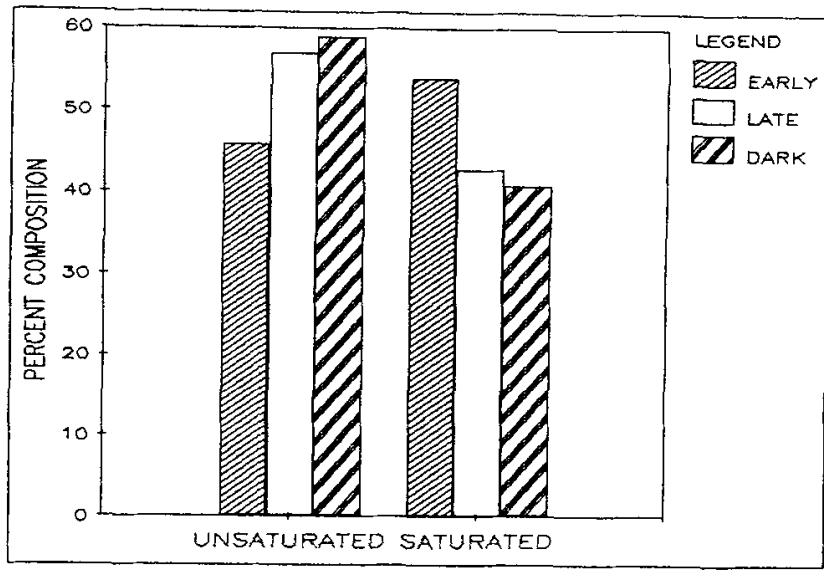

Fig. 1. Change in percent composition of total saturated and unsaturated fatty acids with respect to sampling period in the light/dark cycle.

been associated with silicon-starvation (Lewin et al. 1966, Coombs et al. 1967b) and by short periods of high light intensity (Chisholm et al. 1980, Chisholm and Costello 1980), the cell cycle in diatoms was not believed to be entrained by or phased to the LD cycle as it is in most other phytoplankton taxonomic groups (Chisholm et al. 1980).

Cytological observations that lead us to believe that on the whole, Cyclotella divides during the latter half of the dark period are the following: (1) cells are physically largest during the dark (the dark samples in these experiments were taken during the first three hours of the $8 \mathrm{~h}$ dark period), (2) nucleus, chloroplasts, and mitochondria increase in volume during the latter part of the light period, and (3) the numbers of chloroplasts and mitochondria also

TABLE 2. Variation in fatty acid percent composition with respect to light/dark cycle. Numbers in parentheses are standard errors.

\begin{tabular}{cccc}
\hline Fatty acid & $\begin{array}{c}\text { Early } \\
\text { light period }\end{array}$ & $\begin{array}{c}\text { Late } \\
\text { light period }\end{array}$ & Dark period \\
\hline $14: 0$ & 11.16 & 11.29 & 10.52 \\
& $(0.40)$ & $(0.32)$ & $(0.76)$ \\
$15: 0$ & 1.60 & 1.58 & 1.80 \\
& $(0.05)$ & $(0.10)$ & $(0.42)$ \\
$16: 1$ & 38.51 & 49.12 & 47.73 \\
& $(2.34)$ & $(1.44)$ & $(3.91)$ \\
$16: 0$ & 32.09 & 23.86 & 22.75 \\
& $(1.69)$ & $(1.11)$ & $(2.31)$ \\
$18: 4$ & 0.43 & 0.80 & 1.01 \\
& $(0.09)$ & $(0.07)$ & $(0.10)$ \\
$18: 1$ & 1.56 & 1.34 & 0.93 \\
& $(0.34)$ & $(0.18)$ & $(0.54)$ \\
$18: 0$ & 6.16 & 4.62 & 4.93 \\
& $(1.14)$ & $(0.62)$ & $(2.96)$ \\
$20: 5$ & 5.05 & 6.17 & 9.34 \\
& $(0.45)$ & $(0.40)$ & $(0.46)$ \\
All others & 3.45 & 1.23 & 1.00 \\
& $(1.19)$ & $(0.20)$ & $(0.63)$ \\
Sample size & $\mathrm{n}=8$ & $\mathrm{n}=36$ & $\mathrm{n}=4$ \\
\hline
\end{tabular}


TABLE 3. Morphometric summary of all control data and changes in values with respect to light/dark cycle. Numbers reported are $N_{y}=$ number per volume ${ }^{\mathrm{a}}, V_{\mathrm{v}}=$ relative volume. ${ }^{\mathrm{b}}$ Numbers in parentheses are standard errors.

\begin{tabular}{|c|c|c|c|c|}
\hline & Early & Late & Dark & Al! \\
\hline Chloroplast $\mathrm{V}_{\mathrm{V}}$ & $\begin{array}{l}21.49 \\
(0.69)\end{array}$ & $\begin{array}{l}22.10 \\
(0.65)\end{array}$ & $\begin{array}{l}28.15 \\
(1.62)\end{array}$ & $\begin{array}{l}22.64 \\
(0.50)\end{array}$ \\
\hline Chloroplast lipid $V_{V}$ & $\begin{array}{c}1.09 \\
(0.09)\end{array}$ & $\begin{array}{c}0.78 \\
(0.05)\end{array}$ & $\begin{array}{c}0.81 \\
(0.10)\end{array}$ & $\begin{array}{c}0.86 \\
(0.04)\end{array}$ \\
\hline Mitochondria $V_{V}$ & $\begin{array}{c}3.54 \\
(0.23)\end{array}$ & $\begin{array}{c}3.94 \\
(0.18)\end{array}$ & $\begin{array}{l}3.50 \\
(0.31)\end{array}$ & $\begin{array}{l}3.80 \\
(0.13)\end{array}$ \\
\hline Av-like $V_{v^{c}}$ & $\begin{array}{c}0.57 \\
(0.20)\end{array}$ & $\begin{array}{c}0.34 \\
(0.06)\end{array}$ & $\begin{array}{c}0.17 \\
(0.07)\end{array}$ & $\begin{array}{c}0.37 \\
(0.06)\end{array}$ \\
\hline Lipid $V_{v}$ & $\begin{array}{c}3.05 \\
(0.45)\end{array}$ & $\begin{array}{c}5.96 \\
(0.45)\end{array}$ & $\begin{array}{c}9.97 \\
(2.01)\end{array}$ & $\begin{array}{c}5.76 \\
(0.40)\end{array}$ \\
\hline Vacuole $V_{v}$ & $\begin{array}{l}23.05 \\
(1.13)\end{array}$ & $\begin{array}{l}19.05 \\
(0.56)\end{array}$ & $\begin{array}{l}17.13 \\
(1.71)\end{array}$ & $\begin{array}{l}19.73 \\
(0.50)\end{array}$ \\
\hline Other $V_{v}$ & $\begin{array}{l}17.62 \\
(0.58)\end{array}$ & $\begin{array}{l}17.37 \\
(0.37)\end{array}$ & $\begin{array}{l}15.56 \\
(0.83)\end{array}$ & $\begin{array}{l}17.22 \\
(0.29)\end{array}$ \\
\hline Nucleus $V_{V}$ & $\begin{array}{l}14.87 \\
(0.89)\end{array}$ & $\begin{array}{l}16.56 \\
(0.66)\end{array}$ & $\begin{array}{l}10.64 \\
(1.63)\end{array}$ & $\begin{array}{l}15.53 \\
(0.52)\end{array}$ \\
\hline Frustule $\mathrm{V}_{\mathrm{V}}$ & $\begin{array}{l}12.06 \\
(0.30)\end{array}$ & $\begin{array}{l}11.55 \\
(0.23)\end{array}$ & $\begin{array}{l}11.94 \\
(0.41)\end{array}$ & $\begin{array}{l}11.71 \\
(0.17)\end{array}$ \\
\hline Polyphosphate $V_{V}$ & $\begin{array}{c}1.67 \\
(0.24)\end{array}$ & $\begin{array}{c}1.45 \\
(0.12)\end{array}$ & $\begin{array}{c}1.63 \\
(0.31)\end{array}$ & $\begin{array}{c}1.52 \\
(0.10)\end{array}$ \\
\hline Fibrous Vacuole $V_{V}$ & $\begin{array}{c}0.98 \\
(0.12)\end{array}$ & $\begin{array}{l}0.90 \\
(0.14)\end{array}$ & $\begin{array}{l}0.50 \\
(0.25)\end{array}$ & $\begin{array}{c}0.87 \\
(0.10)\end{array}$ \\
\hline Chloroplast $\mathrm{N}_{\mathrm{V}}$ & $\begin{array}{c}0.131 \\
(0.007)\end{array}$ & $\begin{array}{c}0.162 \\
(0.008)\end{array}$ & $\begin{array}{c}0.137 \\
(0.011)\end{array}$ & $\begin{array}{c}0.152 \\
(0.006)\end{array}$ \\
\hline Chloroplast lipid $\mathrm{N}_{v}$ & $\begin{array}{l}18.14 \\
(2.11)\end{array}$ & $\begin{array}{l}27.37 \\
(8.22)\end{array}$ & $\begin{array}{l}15.64 \\
(2.71)\end{array}$ & $\begin{array}{l}24.02 \\
(5.51)\end{array}$ \\
\hline Mitochondria $N_{V}$ & $\begin{array}{c}0.071 \\
(0.005)\end{array}$ & $\begin{array}{c}0.101 \\
(0.006)\end{array}$ & $\begin{array}{c}0.096 \\
(0.011)\end{array}$ & $\begin{array}{c}0.094 \\
(0.004)\end{array}$ \\
\hline Polyphosphate $N_{V}$ & $\begin{array}{r}0.883 \\
(0.139) \\
\end{array}$ & $\begin{array}{c}0.587 \\
(0.070) \\
\end{array}$ & $\begin{array}{r}0.680 \\
(0.153) \\
\end{array}$ & $\begin{array}{r}0.654 \\
(0.058) \\
\end{array}$ \\
\hline $\begin{array}{l}\text { Sample size } \\
\text { Average cell volume }\end{array}$ & $\begin{array}{c}\mathrm{n}=100 \\
253 \pm \\
6 \mu \mathrm{m}^{3}\end{array}$ & $\begin{array}{c}\mathrm{n}=300 \\
277 \pm \\
4 \mu \mathrm{m}^{3}\end{array}$ & $\begin{array}{l}\mathrm{n}=50 \\
297 \pm \\
10 \mu \mathrm{m}^{3}\end{array}$ & $\begin{array}{c}\mathrm{n}=450 \\
274 \pm \\
3 \mu \mathrm{m}^{3}\end{array}$ \\
\hline
\end{tabular}

$\mathrm{N}_{V}=$ no. per $\mu \mathrm{m}^{3}$.

b $V_{v}=$ relative volume is comparable to percent composition and is expressed as a percentage of the total cell volume. Absolute volume can be determined by multiplying relative volume times the average cell volume.

c Av = autophagic-like vacuole.

increase during the late light period and are at their lowest numbers during the early light period. Gaffal et al. (1982) found that absolute nuclear volume increases during the period of interphase growth up to the initial stages of mitosis.

While these data suggest that the population of cells, on the whole, divides at night, it also demonstrates that the cells are not rigidly synchronized to the light/dark cycle, in agreement with Chisholm and Costello (1980). Non-synchronous cell cycle timing can be advantageous where diatom populations are subjected to widely varying environmental parameters and can be a survival strategy (Chisholm 1981, Cosper 1982, Sicko-Goad 1986, Sicko-Goad et al. 1986b).

Data presented here are in agreement with those presented by Atkinson et al. (1974) for synchronized

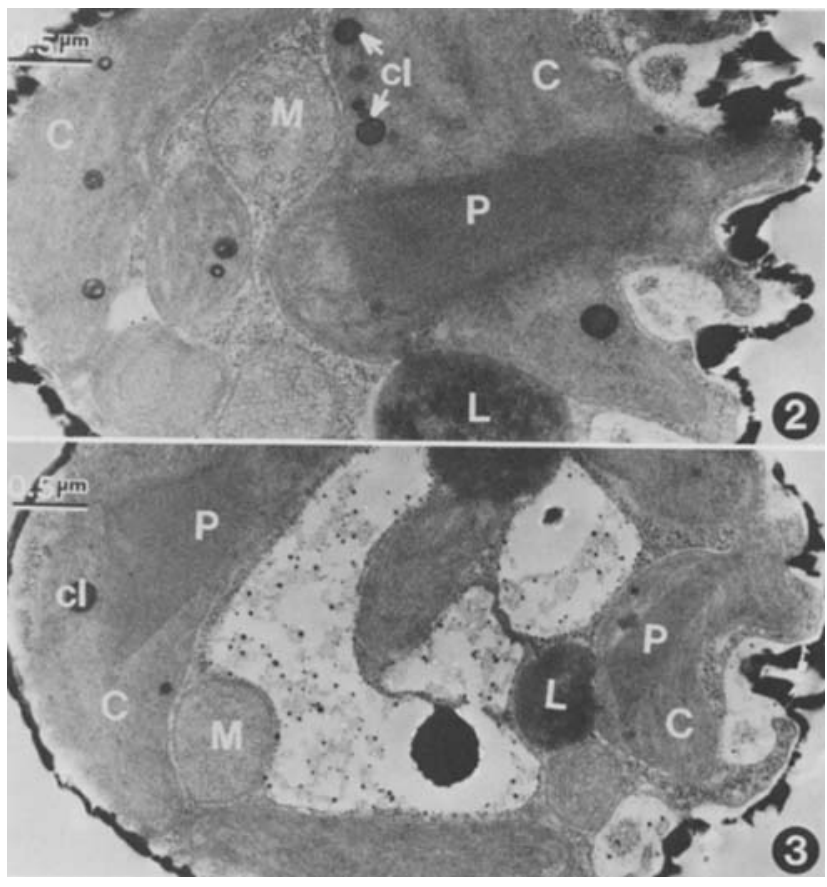

Figs. 2, 3. Electron micrographs of cells sampled during the dark. Note large chloroplasts (C) with pyrenoid (P) and lipid droplets (cl). Mitochondria (M) and lipid (L) are also present.

cultures of Chlorella fusca var. vacuolata. For example, Atkinson et al. (1974) reported that starch reserves are depleted during the process of cytokinesis which occurs during the dark. 'They also reported that the first starch to disappear was that around the pyrenoid and that consumption began during the last few hours of photosynthesis. Puiseux-Dao (1981) reported an increase in chloroplast storage droplets (both numbers and size) at the beginning of the light period. Similarly, in Cyclotella both vacuolar and chloroplast lipid reserves are highest during the early part of the dark period and lowest in the early light period. Thus it appears that storage products accumulate in the light and are utilized in the dark period to sustain cytokinesis and respiration in the absence of photosynthesis. The first storage products to be utilized in Cyclotella are those in the chloroplast although the amount of storage material in the chloroplast is insignificant on a volume basis.

The increase in chloroplast volume during the late light period and early in the dark period is most probably a result of two processes occurring simultaneously: (1) organelle and/or cell division and (2) light reduction. Growth of chloroplasts during the cell cycle was documented by Atkinson et al. (1974) who found the largest relative volumes (an increase of ca. $20 \%$ ) of chloroplast prior to division. However, the cell division process may not entirely account for the increase in chloroplast volume (ca. $30 \%$ ) that occurs in Cyclotella in the dark, assuming that division most often occurs during the latter part 


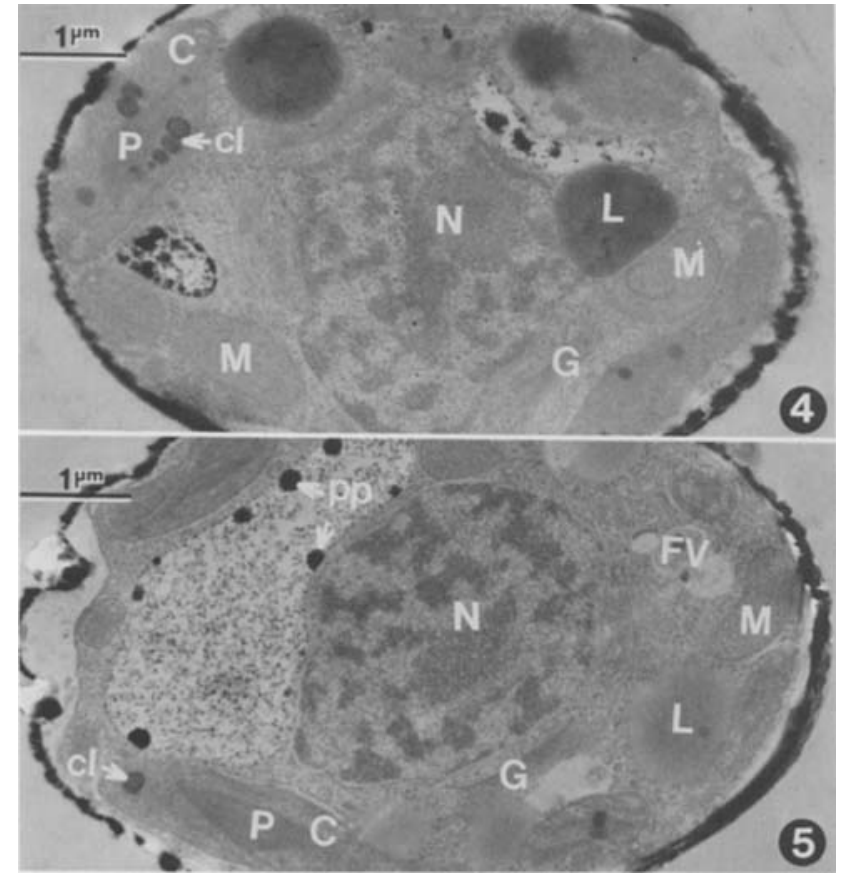

FIGs. 4, 5. Electron micrographs of cells sampled during the early light period. Fig. 4 . Section through the central portion of the cell showing the chloroplast $(\mathrm{C})$ with pyrenoid $(\mathrm{P})$ and lipid droplets $(\mathrm{cl})$, Nucleus $(\mathrm{N})$, mitochondria $(\mathrm{M})$, and $\mathrm{Golgi}(\mathrm{G})$ vesicles. Fig. 5. Grazing section through the vacuolar region showing the distribution of small polyphosphate bodies (pp) in the vacuole and fibrous vacuoles (FV) in the cytoplasm adjacent to the Golgi.

of the dark period. Brown and Richardson (1968) found that in a variety of algae, volumes of both cells and chloroplasts decreased with increasing light intensity and in most cases, pigment content varied directly with chloroplast size. Messer and Ben-Shaul (1972) demonstrated that in Peridinium, cell size and chlorophyll content increased during early growth and decreased with culture age. Aged chloroplasts were narrower and had fewer thylakoids. Holmes (1966) demonstrated that, in four marine diatoms, nutrient deficiencies resulted in both a cessation of chlorophyll $a$ synthesis and a concomitant decrease in the number of chloroplasts resulting from chloroplast division failure rather than degeneration.

Chloroplasts exposed to light are characterized by more dense thylakoid stacking and higher chlorophyll contents (Tageeva et al. 1971, Puiseux-Dao 1981). Since pigment synthesis is largely confined to the light period (Jörgensen 1966, Eppley and Coatsworth 1966, Eppley et al. 1967, Cosper 1982), it seems reasonable to assume that during the dark period pigment content is lower, resulting in less efficient thylakoid packing and an overall increase in chloroplast volume. However, the increase in chloroplast volume that is evident during the latter part of the light cycle is probably a result of enlargement before division.

The fatty acid composition of Cyclotella meneghiniana is similar to reports of fatty acid composition

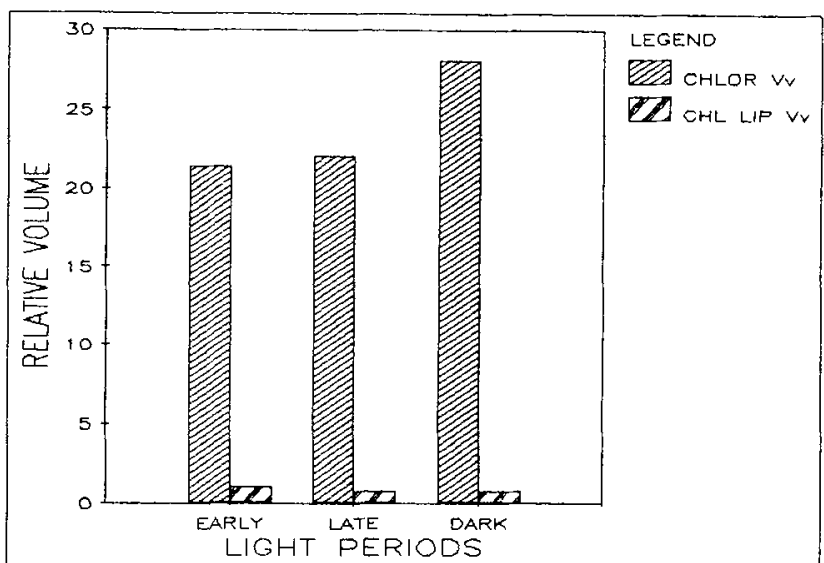

Fic. 6. Change in relative volume (percent of total cell volume) in chloroplast and chloroplast lipid with respect to the light period sampled.

for other diatoms (Kates and Volcani 1966, DeMort et al. 1972, Orcutt and Patterson 1975, Fisher and Schwarzenbach 1978, Ben-Amotz et al. 1985, Nichols et al. 1986, Smith et al. 1986). In addition to the major fatty acids, we found two branched fatty acids (iso-13:0 and iso-14:0) consistently present but in very low quantities. DeMort et al. (1972) reported the presence of a branched C14 fatty acid in Chlamydomonas and a branched C15 fatty acid in seven different algae, including three diatoms. The presence of palmitoleic and palmitic acids as dominants is not suprising. However, in Cyclotella these two fatty acids consistently comprise approximately $70 \%$ of all fatty acids.

Fisher and Schwarzenbach (1978) demonstrated that $\mathrm{C} 16: 0$ and $\mathrm{C} 16: 1$ fatty acids in Thalassiosira pseudonana were stored in triglycerides and were partially or completely oxidized when cells were in the dark for prolonged periods of time and needed energy for metabolism. Similarly, Otsuka and Morimura (1966) found that Chlorella ellipsoidea oxidized large amounts of non-polar fatty acids when the cells

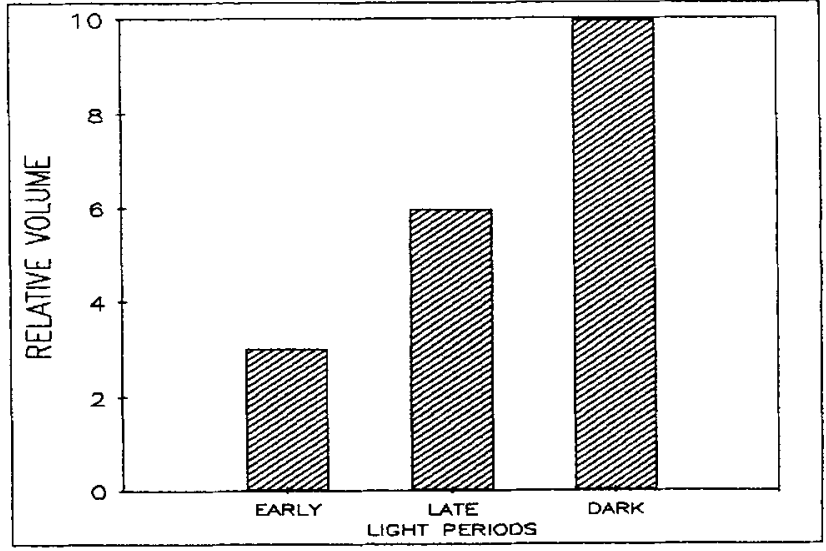

FIG. 7. Change in relative volume (percent of total cell volume) of lipid with respect to the light period sampled. 
needed energy (i.e. in the dark or during cell division). It would appear from our data that the increase in lipid volume as darkness approaches parallels the increase in C16:1 and C20:5 fatty acids, and that the levels of these two fatty acids decline in the early light period.

Previous reports of alterations in fatty acid composition with respect to culture conditions agree remarkably with our data. For example, Kates and Volcani (1966) suggested that the requirement for photosynthesis in diatoms is for a certain degree of unsaturation, which is possibly supplied by the C20:5 fatty acid. This fatty acid in Cyclotella increases late in the light period, reaches its maximum in the dark, and is at its lowest levels in the early part of the light period. In Cyclotella, as in many diatoms, (DeMort et al. 1972), linolenic acid is absent. However, all unsaturated fatty acids are lowest early in the light cycle, presumably when photosynthesis is at its maximum rate, and highest in the dark.

Under stress conditions such as nutrient limitation or high light intensity, algae accumulate lipids (Shaw 1966, DeMort et al. 1972, Shifrin and Chisholm 1981). Similarly, rejuvenating resting cells of the diatom Melosira granulata produce large quantities of lipids during the active photosynthetic stage and utilize these storage products prior to cell division (Sicko-Goad 1986, Sicko-Goad et al. 1986b). Schlenk et al. (1960) and Milner (1948) found that as lipid content increased in Chlorella due to nutrient stresses, the degree of unsaturation of fatty acids decreased significantly. This trend is not apparent in the organism we studied, which was nutrient sufficient. Shifrin and Chisholm (1981) demonstrated that changes in total lipids over a daily cycle are associated directly with cell growth and reproduction. It is most probable that polyunsaturated acids are replenished in the dark for resumption of photosynthesis upon exposure to light. Studies by Pohl and Zurheide (1979) and Tornabene (1981) indicate that in Chlorella and Euglena an increase in total lipids corresponds with formation of polyunsaturated fatty acids.

The data presented here indicate that cyclical changes occur in both quantitative morphology and fatty acid composition with respect to the daily photoperiod. The most dramatic changes include increases in chloroplast and lipid volumes and increases in the C16:1 and C20:5 fatty acids in the dark. Because the changes are so dramatic, it seems apparent that precautions should be taken to separate cell-cycle linked changes from changes that result from stress factors such as environmental perturbations. Studies related to cell cycle changes may aid in elucidating metabolic changes and/or accommodations that occur as a result of toxicant exposure. For example, lipophilic compounds may be stored more when phytoplankton are in the dark or nutrient stressed. Consequently, release of the toxicant would be linked to resumption of active growth or cell division. We have shown synergistic relation- ships between polyphosphate and heavy metal accumulation (Sicko-Goad and Lazinsky 1986) where metals are sequestered in polyphosphate and are made available to the metabolic pool only upon phosphate limitation or starvation. Similarly, environmental conditions may produce physiological responses that make phytoplankton more susceptible to partitioning of lipophilic compounds. In both cases, sequestering of toxicants in storage products may result in toxicant stress to phytoplankton when cells are spatially and temporally removed from the toxicant source and are growing under different environmental parameters. Understanding the normal metabolic processes of phytoplankton will lead to a better understanding of the mode of action of toxicants.

We are grateful to Dr. Susan S. Kilham for kindly providing the culture of Cyclotella. We would also like to thank Dr. E. F. Stoermer for reviewing the manuscript. Supported by Grant R-81068401 from the Office of Exploratory Research, the United States Environmental Protection Agency. Contribution No. 473 of the Great Lakes Research Division.

Ackman R. G., Jangaard, P. M., Hoyle, R. J. \& Brocherhoff, H. 1964. Origin of marine fatty acids. I. Analysis of fatty acids produced by the diatom Skeletonema costatum. J. Fish. Res. Board Canada 2:747-56

Atkinson, A. W., Jr., John, P. C. L. \& Gunning, B. E. S. 1974. The growth and division of the single mitochondrion and other organelles during the cell cycle of Chlorella, studied by quantitative stereology and three dimensional reconstruction. Protoplasma 81:77-109.

Ben-Amotz, A., Tornabene, T. G. \& Thomas, W. H. 1985. Chemical profile of selected species of microalgae with emphasis on lipids. J. Phycol. 21:72-81.

Boyles, D. T. 1980. Toxicity of hydrocarbons and their halogenated derivatives in an aqueous environment. In Afghan, B. K. \& Mackay, D. [Eds.] Hydrocarbons and Halogenated Hydrocarbons in the Aquatic Enzironment. Plenum Press, New York, pp. 545-57.

Brown, T. E. \& Richardson, F. L. 1968. The effect of growth environment on the physiology of algae: Light intensity. $J$. Phycol. 4:38-54.

Canton, J. H., Van Esch, G. J., Greve, P. A. \& van Hellemond, A. B. A. M. 1977. Accumulation and elimination of $\alpha$-hexachlorocyclohexane $(\mathrm{HCH})$ by the marine algae Chlamydomonas and Dunaliella. Water Res. 11:111-5.

Chisholm, S. W. 1981. Temporal patterns of cell division in unicellular algae. Can. Bull. Fish. Aquat. Sci. 210:150-81.

Chisholm, S. W. \& Costello, J. C. 1980. Influence of environmental factors and population composition on the timing of cell division in Thalassiosira fluviatilis (Bacillariophyceae) grown on light/dark cycles. J. Phycol. 16:375-83.

Chisholm, S. W., Morel, F. M. M. \& Slocum, W. S. 1980. The phasing and distribution of cell division cycles in marine diatoms. In Falkowski, P. [Ed.] Primary Productivity in the Sea. Brookhaven Symp. Biol. 31, pp. 281-300.

Clayton, J. R., Pavlou, S. P. \& Breitner, N. F. 1977. Polychlorinated biphenyls in coastal marine zooplankton: bioaccumulation by equilibrium partitioning. Environ. Sci. Technol. $11: 676-82$.

Coombs, J., Darley, W. M., Holm-Hansen, O. \& Volcani, B. E. 1967a. Studies on the biochemistry and fine structure of silica shell formation in diatoms. Chemical composition of Navicula pelliculosa during silicon-starvation synchrony. Plant Physiol. 42:1601-6.

Coombs, J., Spanis, C. \& Volcani, B. E. 1967b. Studies on the biochemistry and fine structure of silica shell formation in diatoms. Photosynthesis and respiration in silicon-starvation synchrony of Navicula pelliculosa. Plant Physiol. 42:1607-11. 
Cosper, E. 1982. Influence of light intensity on diel variations in rates of growth, respiration and organic release of a marine diatom: comparison of diurnally constant and fluctuating light. J. Plankton Res. 4:705-24.

Darley, W. M. 1977. Biochemical composition. In Werner, D. [Ed.] The Biology of Diatoms. University of California Press, Berkeley, pp. 198-223.

DeMort, C. L., Lowry, R., Tinsley, I. \& Phinney, H. K. 1972. The biochemical analysis of some estuarine phytoplankton species. I. Fatty acid composition. J. Phycol. 8:211-16.

Eppley, R. W. \& Coatsworth, J. L. 1966. Culture of the marine phytoplankter, Dunaliella tertiolecta, with light/dark cycles. Arch. Mikrobiol. 55:66-80.

Eppley, R. W., Holmes, R. W. \& Paasche, E. 1967. Periodicity in cell division and physiological behavior of Ditylum brightwellii, a marine plankton diatom, during growth in light/ dark cycles. Arch. Mikrobiol. 56:305-23.

Fisher, N. S. \& Schwarzenbach, R. P. 1978. Fatty acid dynamics in Thalassiosira pseudonana (Bacillariophyceae): Implications for physiological ecology. J. Phycol. 14:143-50.

Fogg, G. E. 1956. Photosynthesis and formation of fats in a diatom. Ann. Bot. 20:265-85.

Gaffal, K. P., Gaffal, S. I. \& Schneider, G. J. 1982. Morphometric analysis of several intracellular events occurring during the vegetative life cycle of the unicellular alga Polytoma papillatum. Protoplasma 1 10:185-95.

Ganf, G. G., Stone, S. J. L. \& Oliver, R. L. 1986. Use of protein to carbohydrate ratios to analyze for nutrient deficiency in phytoplankton. Aust. J. Mar. Freshutat. Res. 37:183-97.

Guillard, R. R. L. 1975. Culture of phytoplankton for feeding marine invertebrates. In Smith W. L. \& Chaney, M. H. [Eds.] Culture of Marine Intertebrate Animals. Plenum Press, New York, pp. 39-59.

Holmes, R. W. 1966. Light microscope observations on cytological manifestations of nitrate, phosphate, and silicate deficiency in four marine centric diatoms. J. Phycol. 2:136-40.

Hutchinson, T. A., Hellebust, J. A., Tam, D., Mackay, D., Mascarenhas, R. A. \& Shiu, W. Y. 1980. The correlation of the toxicity to algae of hydrocarbons and halogenated hydrocarbons with their physical-chemical properties. In Afghan, B. K. \& Mackay, E. [Eds.] Hydrocarbons and Halogenated Hydrocarbons in the Aquatic Environment. Plenum Press, New York, pp. 577-86.

Jörgensen, E. G. 1966. Photosynthetic activity during the life cycle of synchronous Skeletonema cells. Physiol. Plant. 19:78999

Kates, M. \& Volcani, B. E. 1966. Lipid composition of diatoms. Biochion. Biophys. Acta 116:264-78.

Lewin, J. C., Reimann, B. E., Busby, W. F.\& Volcani, B. E. 1966. Silica shell formation in synchronously dividing diatoms. In Cameron, I. L. \& Padilla, G. M. [Eds.] Cell Synchrony. Academic Press, New York, pp. 169-88.

Meier, D. \& Lichtenthaler, H. K. 1981. Ultrastructural development of chloroplasts in radish seedlings grown in highand low-light conditions and in the presence of the herbicide bentazon. Protoplasma 107:195-207.

Messer, G. \& Ben-Shaul, Y. 1972. Changes in chloroplast structure during culture growth of Peridinium cinctum Fa. Westii (Dinophyceae). Phycologia 11:291-99.

Metcalfe, L. D. \& Schmitz, A. A. 1961. The rapid preparation of fatty acid esters for gas chromatographic analysis. Anal. Chem. 33:363-64.

Millie, D. F. 1986. Nutrient-limitation effects on the biochemical composition of Cyclotella meneghiniana (Bacillariophyta): an experimental and statistical analysis. Can. J. Bot. 64:19-26.

Milner, H. W. 1948. The fatty acids of Chlorella. J. Biol. Chem. 176:813-7.

Nichols, P. D., Palmisano, A. C., Smith, G. A. \& White, D. C. 1986. Lipids of the antarctic sea ice diatom Nitzschia cylindrus. Phytochemistry 25:1649-53.

Opute, F. I. 1974. Studies in fat accumulation in Nitzschia palea Kütz. Ann. Bot. 38:889-902.
Orcutt, D. M. \& Patterson, G. W. 1975. Sterol, fatty acid and elemental composition of diatoms grown in chemically defined media. Comp. Biochem. Physiol. 50B:579-83.

Otsuka, H. \& Morimura, Y. 1966. Changes of fatty acid composition of Chlorella ellipsoidea during its cell cycle. Plant Cell. Physiol. 7:663-70.

Pohl, P. \& Zurheide, F. 1979. Fatty acids and lipids in marine algae and the control of their biosynthesis by environmental factors. In Hope, H. A., Levring, T. \& Tanaka, Y. [Eds.] Marine Algae in Pharmaceutical Science. Walter de Gruyter, Berlin, pp. 433-523.

Puiseux-Dao, S. 1981. Cell-cycle events in unicellular algae. Can. Bull. Fish. Aquat. Sci. 210:130-49.

Schlenk, J., Mangold, H. K., Gellerman, J. L., Link, W. E., Morrissett, R. A., Holman, R. T. \& Hayes, T. 1960. Comparative analytical studies of fatty acids of the alga Chlorella pyrenoidosa. J. Am. Oil Chem. Soc. 3:547-52.

Schwarzenbach, R. P.\& Fisher, N. S. 1978. Rapid determination of the molecular weight distribution of total cellular fatty acids using chemical ionization mass spectrometry. $J$. Lipid Res. 19:12-7.

Shaw, R. 1966. Polyunsaturated fatty acids of microorganisms. Adr. Lipid Res, 4:111-74.

Shifrin, N. S. \& Chisholm, S. W. 1981. Phytoplankton lipids: interspecific differences and effects of nitrate, silicate, and light-dark cycles. J. Phycol. 17:374-84.

Sicko-Goad, L. 1986. Rejuvenation of Melosira granulata (Bacillariophyceae) from the anoxic sediments of Douglas Lake, Michigan. II. Electron Microscopy. J. Phycol. 22:28-35.

Sicko-Goad, L., Ladewski, B. G. \& Lazinsky, D. 1986a. Synergistic effects of nutrients and lead on the quantitative ultrastructure of Cyclotella (Bacillariophyceae). Arch. Environ. Contam. Toxicol. 15:291-300.

Sicko-Goad, L. \& Lazinsky, D. 1986. Quantitative ultrastructural changes associated with lead-coupled luxury phosphate uptake and polyphosphate utilization. Arch. Entiron. Contam. Toxicol. 15:617 -27.

Sicko-Goad, L., Schelske, C. L. \& Stoermer, E. F. 1984. Estimation of intracellular carbon and silica content of diatoms from natural assemblages using morphometric techniques. Limnol. Oceanogr. 29:1 170-8.

Sicko-Goad, L., Stoermer, E. F., \& Fahnenstiel, G. 1986b. Rejuvenation of Melosira granulata (Bacillariophyceae) from the anoxic sediments of Douglas Lake, Michigan. I. Light microscopy and ${ }^{14} \mathrm{C}$ uptake. J. Phycol. 22:22-8.

Sicko-Goad, L., Stoermer, E. F. \& Ladewski, B. G. 1977. A morphometric method for correcting phytoplankton cell volume estimates. Protoplasma 93:147-63.

Smith, G. A., Nichols, P. D. \& White, D. C. 1986 . Fatty acid composition and microbial activity of benthic marine sediment from McMurdo Sound, Antarctica. FEMS Microbiol. Ecol. 38:219-31.

Smith, R. E. H. \& Geider, R. J. 1985. Kinetics of intracellular carbon allocation in a marine diatom. J. Exp. Mar. Biol. Ecol. 93:191-210.

Tageeva, S. V., Abdullaev, K. A. \& Shvirst, E. M. 1971. Quantitative morphometry of cytoplasmic membranes as exemplified in the lamellar structures of chloroplasts. Doklady Akademï Nauk USSR 199:1171-3.

Tornabene, T. G. 1981. Formation of hydrocarbons by bacteria and algae. In Bollaender, A., Rabson, R., Pietro, S., Valentine, R. \& Wolfe, R. [Eds.] Trends in the Biology of Fermentation for Fuels and Chemicals. Plenum, New York, pp. 421-38.

Varum, K. M. \& Mykelstad, S. 1984. Effects of light, salinity and nutrient limitation on the production of $\beta-1,3-\mathrm{D}$ glucan and Exo-D-glucanase activity in Skeletonema costatum (Grev.) Cleve. J. Exp. Mar. Biol. Ecol. 83;13-25.

Watson, M. L. 1958. Staining tissue sections for electron microscopy with heavy metals. $J$. Biophys. Biochem. Cytol. 4:475-8.

Werner, D. 1966. Die Kieselsaure im Stoffwechsel von Cyclotella cryptica, Reimann, Lewin \& Guillard. Arch. Mikrobiol. 55:278308. 